\title{
Antimicrobial Activity of Barbatimão Glycol Extract on Streptococcus mutans
}

\section{Atividade Antimicrobiana do Extrato Glicólico Barbatimão Sobre o Streptococcus mutans}

\author{
Carlos Eduardo Silva da Costa ${ }^{\mathrm{a}}$; Rayana Soares de Andrade ${ }^{\mathrm{a}}$; Ricardo Sérgio Couto de Almeida ${ }^{\mathrm{b}}$; Sandra Kiss Moura ${ }^{\mathrm{c}}$; \\ Sandra Mara Maciela; ${ }^{\text {; }}$ Regina Célia Poli-Frederico*a
}

aUNOPAR, Stricto Sensu Post-Graduate Program in Dentistry. PR, Brazil.

${ }^{\mathrm{b} S}$ State University of Londrina, Department of Microbiology. PR, Brazil.

'Nove de Julho University,Post-Graduate Program in Biophotonics Applied to Health Science. SP, Brazil.

*E-mail: reginafrederico@yahoo.com.br

Recebido em: 07/02/2020

Aprovado em: 08/06/2020

\begin{abstract}
The study of medicinal plants with antimicrobial action is a current issue, mainly due to the increase of bacterial resistance and the need for new antimicrobials with equal or greater efficacy, low cost and low side effects. The constant search for new products with bactericidal potential on oral microorganisms, mainly of natural origin, has grown considerably in recent years. The objective of this research was to evaluate the efficiency of concentrations of Barbatimão glycolic extract solution (Stryphnodendronadstringens) in inhibiting the bacteria growth associated with in vitro dental caries. Sixteen different concentrations of Barbatimão glycolic extract were prepared $(0 \%, 1.56 \%, 3.12 \%, 4.68 \%, 6.25 \%$, $7.81 \%, 9.37 \%, 10.93,12,5 \%, 25 \%, 37.5 \%, 50 \%, 62.5 \%, 75 \%, 87.5 \%, 100 \%$ ) and the $2 \%$ chlorhexidine solution were used as the control group. The prepared solutions were tested on the bacterial strain of Streptococcus mutans. Bacterial growth was observed on plates containing $\mathrm{BHI}$ culture medium. Barbatimão concentrates were placed in wells made in the culture medium and each plate was incubated in a $\mathrm{CO} 2$ oven $\left(37^{\circ} \mathrm{C} / 24\right.$ hours). The test was performed in triplicate, resulting in the absence of bacterial inhibition at the tested barbatimão concentrations, with bacterial inhibition of $2 \%$ chlorhexidine being positive. It is concluded that the barbatimão glycolic extract in the analyzed concentrations does not present bactericidal action on Streptococcus mutans.
\end{abstract}

Keywords: Dental Caries. Microbiota. Stryphnodendronbarbatimam

\section{Resumo}

O estudo de plantas medicinais com ação antimicrobiana é um assunto atual, principalmente devido ao aumento da resistência bacteriana e a necessidade de novos antimicrobianos com igual ou maior eficácia, baixo custo e baixos efeitos colaterais. A busca constante de novos produtos com potencial bactericida sobre os micro-organismos orais, principalmente de origem natural tem crescido bastante nos últimos anos. O objetivo desta pesquisa foi avaliar a eficiência de diferentes concentrações de solução de extrato glicólico de Barbatimão (Stryphnodendron adstringens) na inibição do crescimento de bactérias associadas a cárie dental in vitro.Foram preparadas dezesseis concentrações do extrato glicólico do Barbatimão (0\%, 1,56\%, 3,12\%, 4,68\%, 6,25\%, 7,81\%, 9,37\%, 10,93, 12,5\%, 25\%, 37,5\%, 50\%, 62,5\%, 75\%, 87,5\%, 100\%) e como grupo controle foi utilizada a solução de clorexidina $2 \%$. As soluções preparadas foram testadas sobre a cepa bacteriana de Streptococcus mutans. O crescimento bacteriano foi observado em placas contendo meio de cultura BHI. As concentracões do barbatimão foram colocadas em poços realizados no meio de cultura e cada placa foi incubada em estufa de CO2 ( $37^{\circ} \mathrm{C} / 24$ horas). O teste foi realizado em triplicata, tendo como resultado a ausência de inibição bacteriana para as concentrações do barbatimão testadas, sendo positiva a inibição bacteriana para clorexidina a $2 \%$. Conclui-se que o extrato glicólico de barbatimão nas concentrações analisadas, não apresenta ação bactericida sobre o Streptococcus mutans.

Palavras-chave: Cárie Dentária. Microbiota. Barbatimão

\section{Introduction}

Dental caries, among the pathologies affecting the oral cavity, are the one that presents the highest world prevalence, being considered a multifactorial disease, since its origin depends on the interaction of essential factors, such as: host (tooth), micro-organism, diet and time ${ }^{1}$.

Concerning the micro-organisms present in the oral cavity, there are species that participate in the formation and progression process of dental caries in an important way, Streptococcus mutans being considered the micro-organism that presents the greatest cariogenic potential and is directly associated with its onset ${ }^{2}$.
Bacterial plaque control plays an important role in the dental caries prevention, not only in the decrease of oral bacteria, but also in the cavities cleaning process after cavitary preparations, with the objective of avoiding a new incidence of dental caries. The use of antimicrobial agents in this control is widely used and presents satisfactory results, and chlorhexidine is the most widely used and the most effective, mainly because it is a potent antimicrobial agent and plays an important role in the inhibition of metalloproteinases present in the dental matrix ${ }^{3}$.

The constant search for new products with bactericidal potential on oral microorganisms, mainly of natural origin, 
has brought about several studies with that objective. This is due to the inefficiency of some synthetic products, their side effects and also to the search for products with lower production costs and lower adverse effects ${ }^{4}$.

Phyto therapy medicinal products are pharmaceutical preparations (extracts, dyes, ointments and capsules) of medicinal herbs obtained from one or more plants. They exhibit several advantages for therapeutic use, such as low cost and reduced adverse effects, in relation to synthetic drugs. Among these phytoterapic products, barbatimão (Stryphonodendronadstringens), a medicinal plant, present mainly in the Brazilian cerrado, exhibits antibacterial, antiinflammatory, antiseptic and hemostatic efficacy ${ }^{5}$.

Barbatimão seems to present antimicrobial activity on Streptococcus mutans and other bacteria involved in the caries process. Therefore, this research aimed to evaluate the efficacy of different concentrations of Barbatimão glycolic extract solution (Stryphnodendron adstringens) in the inhibition of Streptococcus mutans growth in vitro.

\section{Material and Methods}

The tests were conducted at the Laboratory of Oral Microbiology, at the State University of Londrina (UEL), Londrina-PR.

\subsection{Obtaining Barbatimão extract}

The barbatimão glycolic extract (Stryphnodendron adstringens) was purchased in its pure, certified composition from the company Empresa Império do Banho - ME. The glycolic extraction does not present cytotoxicity. Sixteen concentrations of the extract were obtained from the same company, using propylene glycol solvent in water, namely: $0 \%, 1.56 \%, 3.12 \%, 4.68 \%, 6.25 \%, 7.81 \%, 9.37 \%, 10.93$, $12.5 \%, 25 \%, 37.5 \%, 50 \%, 62.5 \%, 75 \%, 87.5 \%, 100 \%$. As a control group the $2 \%$ chlorhexidine solution was used which was purchased from Maquira Indústria de Produtos Odontológicos Ltda.

\subsection{Cultivation of Microorganisms}

The bacteria used for the tests were Streptococcus mutans ATCC 700610 strain. The plates containing these microorganisms were maintained at a temperature from $4{ }^{\circ} \mathrm{C}$ to $8{ }^{\circ} \mathrm{C}$ in BHI-agar medium (Brainheartinfusion agar). To perform the tests, five colonies of each Streptococcus mutans plate with disposable handle were collected in a sterile environment that were immersed and dispersed in Falcon tubes containing $10 \mathrm{~mL}$ of BHI broth (Brainheartinfusionbroth). They were then incubated for 16 hours in a $\mathrm{CO}_{2}$ oven $(5 \%)$ at $37{ }^{\circ} \mathrm{C}$ without agitation.

\subsection{Antimicrobial test: in agar diffusion}

After 16 hours of incubation, the inocula were washed three times with phosphate-saline buffer (PBS) and a bacterial suspension diluted in PBS with turbidity similar to the McFarland 0.5 scale in a transparent glass tube, in sterile environment, totaling 1.5 x $108 \mathrm{CFU} / \mathrm{mL}$.

A thin layer of agar/water was then deposited at the bottom of the plate $(10 \mathrm{ml})$, followed by a layer of $20 \mathrm{ml}$ BHI-agar (1,5\%) containing $200 \mu \mathrm{l}$ of the microorganism suspension, deposited on the agar/water. This same layer of BHI-Agar was perforated for the production of wells with a blue $1 \mathrm{ml}$ tip, after perforation, the lids were removed from each well, resulting thus in an agar/-water layer bottom. In each well, about $0.2 \mathrm{ml}$ of the barbatimão formulations containing the concentrations respectively: $0 \%, 1.56 \%, 3.12 \%, 4.68 \%$, $6.25 \%, 7.81 \%, 9.37 \%, 10.93,12.5 \%, 25 \%, 37.5 \%, 50 \%$, $62.5 \%, 75 \%, 87.5 \%, 100 \%$ were added. The control group was made with $2 \%$ chlorhexidine. After 24 hours, inhibition halos were measured with the aid of an electronic caliper . Then, the inhibition halo was subtracted by the well diameter. The results were expressed in millimeters.

\section{Results and Discussion}

It was observed that none of the tested concentrations of the barbatimão glycolic extract ( Stryphnodendronadstringens) showed potential for inhibition of bacterial growth of Streptococcus mutans .

The current society demonstrates a concern about nature conservation, as well as the search for knowledge of the use of plant species. The transformation of a plant into a technically elaborated product requires studies to validate plant species in order to prove safety and efficacy. More than a hundred compounds derived from natural products are in the laboratory test phase, for the most diverse uses in treatment of diseases. The evaluation of antimicrobial activity of glycolic extract of barbatimão barks (Stryphnodendronadstringens) corroborates this current trend of developing and testing drugs produced from natural plants, mainly for micro-organism control ${ }^{6}$.

Medicinal plants produce a wide aspect of pharmacological actions, with the emphasis on anti-inflammatory and antimicrobial activities ${ }^{7}$, and the barbatimão plant extract is a natural product widely used as a healing, anti-inflammatory, hemostatic, anti-edematogenic, antiseptic agent ${ }^{8}$.

Orlando ${ }^{9}$ observed in vitro antimicrobial activity of crude hydroalcoholic extract of barbatimão bark ( Stryphnodendronadstringens) for Enterococcusfaecalis, Kocuriarhizophila, Escherichia coli, Neisseria gonorrhoeae, Pseudomonas aeruginosa, Shigellaflexneri, Staphylococcus aureus, Klebsiellapneumoniae, Candidaalbicans and Candidakrusei.

Soares et al..$^{10}$ evaluated the efficacy of barbatimão crude extract (Stryphnodendronadstringens) obtained by means of hydroalcoholic extraction, before micro-organisms responsible for dental caries. Strains of the following micro-organisms were used: Enterococcusfaecalis, Streptococcus salivarius, Streptococcus sanguinis, Streptococcus mitis, Streptococcus 
mutans, Streptococcus sobrinus and Lactobacillus casei. Antibacterial activity was observed on all of them, and the best results were on $S$. mitis and L. casei strains, the minimum inhibitory concentration (MIC) varied from 350 to $>400 \mu \mathrm{g} /$ $\mathrm{mL}$.

Pereira etal. ${ }^{11}$ also confirmed the efficiency of the barbatimão hydroalcoholic extract (Stryphnodendronadstringens) in relation to the following pathogenic microorganisms in the oral cavity: Candidaalbicans, Streptococcus mutans, Stapylococcus aureus and Aggregatibacteractinomycetemcomitans. The barbatimão extracts showed antibacterial activity against all the tested micro-organisms, except for A. actinomycetemcomitans.

Miranda ${ }^{12}$ used barbatimão hydroalcoholic extract (Stryphnodendronadstringens) as endodontic medication. The tests were performed in microplates with diffusion in wells of the extract, incubation at $35^{\circ}$ from 24 to 48 hours, where the bactericidal action for the micro-organisms was verified: Prevotellanigrescens, Actinomycesnaeslundii, Porphyromonasgingivalis, Enterococcusfaecalis and Haemophilusactinomycetemcomitans.

Although the above studies demonstrate the barbatimão action (Stryphnodendronadstringens) as antimicrobial, the use of hydroalcoholic extraction, the control of the solvent (alcohol) does not appear in the studies, which does not clarify whether there was interference of the solvent used in the barbatimão bactericidal action ${ }^{9-12}$.

The results of the present study contradict data from previous studies 9-12 where inhibition of bacterial growth was observed, with barbatimão bactericidal action (Stryphnodendronadstringens) in its presentation as hydroalcoholic extract, which was not confirmed in its presentation as glycolic extract used in this study, suggesting an interference in the form of extraction of the barbatimão active principles (tannins) in relation to the solvent used.

Cowan ${ }^{13}$ emphasizes that there is a better extraction of the active principles (tannins phenolic compounds, flavonoids and terpenoids) by means of hydroalcoholic extraction. Whereas Ardisson et al. ${ }^{14}$ found a better characterization of the barbatimão (tannins) proprieties in the use of propylene glycol in water. The concentration of $80 \%$ propylene glycol was more selective.

Chlorhexidine as a positive control obtained a satisfactory result for the inhibition of the growth of Streptococcus mutans, confirming its great efficacy as a bactericidal agent ${ }^{15,16}$ Growth inhibition halo was observed above $20 \mathrm{~mm}$, which corroborates the findings of Festuccia et al. ${ }^{17}$.

Moreira et $a l .{ }^{18}$ in the in vitro evaluation of antimicrobial activity of buccal antiseptics, verified inhibition halo with chlorhexidine above $20 \mathrm{~mm}$. Costa et al. ${ }^{19}$ observed in vitro the antimicrobial action of plant extracts on Enterococcusfaecalis , using chlorhexidine as a positive control, obtaining an inhibition halo of $24.52 \mathrm{~mm}$.

\section{Conclusion}

Based on the results obtained in the present study, it can be concluded that, by the methodology applied, the different concentrations of barbatimão glycolic extract (Stryphnodendronadstrigens) were not able to foster bactericidal action in the colonies of Streptococcus mutans.

\section{References}

1. Fejerskov O, KiddRcDadestc. Cárie dentária: a doença e seu tratamento clínico. São Paulo: Santos; 2005.

2. Leites ACBR, Pinto MB, Sousa ERS. Aspectos microbiológicos da cárie dental. Salusvita 2006;25(2):23952 .

3. Tenuta LMA, Lima JEO, Cardoso CL, Tabchoury CPM, Cury JA. Effect of period of plaque accumulation and salivary factors on enamel demineralization and plaque composition in situ. Pesq Odontol Brás 2003;17(4):326-31. doi: https:// doi.org/10.1590/S1517-74912003000400006

4. Hernandes L, Pereira LMS, Palazzo F, Mello JCPM. Wound-healing evaluation of ointment from Stryphnodendronadstringens (barbatimão) in rat. Braz J Pharm Sci 2010;46(3). doi: https://doi.org/10.1590/S198482502010000300005

5. Eller SC, Feitosa VA, Antunes RM. Avaliação antimicrobiana de extratos vegetais e possível interação farmacológica in vitro.Rev Ciênc Farm Bás Aplic 2015;36(1):131-6.

6. Machado KC, Machado KC, Junior ALG, Freitas RM. Uso de Produtos naturais para o tratamento de doenças infecciosas: prospecção tecnológica. Rev Geintec 2014;4(1):665-72. doi: https://doi.org/10.7198/geintec.v4i1.216

7. Niero R. Aspectos químicos e biológicos de plantas medicinais e considerações sobre fitoterápicos. In: Chechinel Filho V, Bresolin TMB. Ciências químico-farmacêuticas: Contribuição ao desenvolvimento de novos fármacos e medicamentos. Itajaí SC: Unival; 2003. p.150-215

8. Vasconcelos MCA, Rodovalho NCM, Pott VJ, Ferreira AMT, Arruda ALA, Marques MCS, et al. Avaliação de atividade biológicas das sementes de StryphnodendronobovatumBenth (Leguminosae). Rev Bras Farmacogn 2004;14:121-7. doi: https://doi.org/10.1590/S0102-695X2004000200005

9. Orlando SC. Avaliação da atividade antimicrobiana do extrato hidroalcoólico bruto da casca de Stryphnodendronadstringens (Martius) Coville (Barbatimão). Franca: Universidade de Franca; 2005.

10. Soares SP, Vinholis AHC, Casemiro LA, Silva MLA, Cunha WR, Martins CHG. Atividade antibacteriana do extrato hidroalcoólico bruto de Stryphnodendronadstringens sobre microorganismos da cárie dental. Rev Odonto Ciênc 2008;23(2):141-4

11. Pereira C, Moreno CS, Carvalho C. Usos farmacológicos do Stryphnodendronadstringens (MAR.) - Barbatimão. Rev Panorâmica On-Line 2013(15):127-37.

12. Miranda MA. Atividade Antimicrobiana das Soluções de Barbatimão, Mamona e Clorexidina utilizadas na Endodontia. Avaliação comparativa "in vitro". Ribeirão Preto: Universidade de São Paulo; 2010. doi: 10.11606/D.58.2010. tde-18102010-164835

13. Cowar MM. Plants products as antimicrobial agents. Clin Microb Rew 1999(12):564-82. 
14. Ardisson L, Godoy JS, Ferreira LAM, Stehmann JR, Brandão MGL. Preparação e caracterização de extratos glicólicos enriquecidos em taninos a partir das cascas de Stryphnodendron adstringens (Mart.) Coville (Barbatimão). Rev Bras Farmacog 2002;12(1):27-34. doi: https://doi. org/10.1590/S0102-695X2002000100004.

15. Gomes BPFA, Vianna MEV, Zaia AA, Almeida JFA, SouzaFilho FJ, Ferraz CCR. Chlorhexidine in Endodontics. Braz Dental J 2013;24(2):89-102. doi: https://doi. org/10.1590/0103-6440201302188

16. Hortense SR, Carvalho ES, Carvalho FS, Silva RPR, Bastos JRM, Bastos RS. Uso da clorexidina como agente preventivo e terapêutico na odontologia. Rev Odontol Unicid 2010;22(2):178-84. doi: 10.26843/ro_unicid.v22i2.414
17. Festuccia JMZ, Andrade Dd, Beraldo CC, Shimura CMN, Watanabe E. Staphylococcus aureus e a atividade in vitro da clorexidina. Rev Ciênc Farm Básica Apl 2013;34(3):411-5.

18. Moreira ACA, Pereira MHQ, Porto MR, Rocha LAP, Nascimento BC, Andrade PM. Avaliação in vitro da atividade antimicrobiana de antissépticos bucais. Rev Cienc Med Biol 2009;8(2):153-61.doi: 10.9771/cmbio.v8i2.4065

19. Costa EMMB, Barbosa AS, Arruda TA, Oliveira PT, Dametto FR, Carvalho RA, et al. Estudo in vitro da ação antimicrobiana de extratos de plantas contra Enterococcusfaecalis. J Bras Patol Med Lab 2010;46(3):175-80. doi: https://doi. org/10.1590/S1676-24442010000300004 